This is the final peer-reviewed accepted manuscript of:

Nurdan Kuban \& Marco Pretelli (2021) Industrial Heritage Assessment and Guidelines for the Architectural Conservation of Hydroelectric Plants, International Journal of Architectural Heritage, 15:10, 1526-1546

The final published version is available online at: $\underline{10.1080 / 15583058.2019 .1707329}$

Rights / License:

The terms and conditions for the reuse of this version of the manuscript are specified in the publishing policy. For all terms of use and more information see the publisher's website.

This item was downloaded from IRIS Università di Bologna (https://cris.unibo.it/)

When citing, please refer to the published version. 


\section{Industrial heritage assessment and guidelines for the architectural}

conservation of hydroelectric plants

Nurdan Kuban ${ }^{1}$, Marco Pretelli²

${ }^{1}$ Faculty of Architecture and Design, Kocaeli University; Turkey

${ }^{2}$ Faculty of Architecture, Bologna University; Italy 


\title{
Industrial heritage assessment and guidelines for the architectural conservation of hydroelectric plants
}

\begin{abstract}
Hydroelectric plants, constructed as modern, industrial, innovative and technological structures of the 20th century, after approximately a century of existence, have become subjects of industrial heritage. Within the article, the interdisciplinary field is approached through the perspective of architectural conservation with consultancies of experts from related disciplines. The study discusses hydroelectric facilities of the past century in terms of industrial heritage focusing on their features, types and elements, investigates the theoretical framework in order to specify criteria for their assessment as cultural heritage, and develops a guideline for the architectural preservation, conservation, restoration and re-use of these structures. The proposed set of criteria and the guideline are applied for 17 selected case studies of dams and powerhouses in Northern ItaliaItaly. The process and the results of the study are discussed with a purpose of serving as a model for further studies on the preservation, conservation and restoration of hydroelectric plants.
\end{abstract}

Keywords: industrial heritage, hydroelectric plants, dams, architectural conservation, assessment criteria

\section{Introduction:}

"Like silent witnesses to the past, large dams built to create manmade reservoirs often deserve the privilege of monument status for their age, function, performance, grandeur and even solemnity. Due to their amazing architectural characteristics and to both their appurtenant temporary and permanent works for diversion, use, and release of water, well-designed dams and reservoirs integrate themselves into the environment, positively changing the features of the surrounding landscape and the liveability of the area" (Japelli 2005, 1).

As is true with all perceptive conceptions which create beneficial controversies and debates on the agenda, throughout history, conservation approach regarding cultural heritage has also been developing, evolving and expanding to include new subjects and 
different perspectives. Hydroelectric plants and dams, which had been constructed as modern, revolutionary, technological structures of the 20th century, have become subjects of industrial heritage. Substantially increasing the amount of energy produced from natural sources, they had been among the most extensive investments for the production of electricity throughout the last century. Since then, these facilities have usually been perceived as a specialized field of engineering; besides, - - as a result of the interaction with nature-_- ecologists and environmentalists have also been included in discussions on hydroelectric plants. In the field of cultural heritage,__-focusing on settlements and monuments buried underwater or deteriorated in other means-_- dams and hydroelectric plants have commonly been regarded as threats over cultural assets. However, it is important to be aware of the fact that these facilities, after almost a hundred years of existence, have also gained cultural value, and it is crucial to contemplate the future of these structures by bringing them on the agenda.

The article discusses the preservation / conservation of hydroelectric plants of the 20th century as industrial heritage by investigating the answers to the three fundamental questions which need to be reconsidered in each case of cultural heritage management: 'what should be conserved?'; ‘why should it be conserved?'; 'how should it be conserved?.' In order to discuss hydroelectric plants as industrial heritage, initially, the technical features, types and elements of the facilities are introduced in the study. Regarding the reasons for conservation, the theoretical framework is presented, including charters on industrial heritage, and legislations and principles applied for the register of hydroelectric facilities in various countries. The general framework regarding the conservation of industrial heritage is defined in the Nizhny Tagil Charter and the Dublin Principles (TICCIH 2003; Dublin Principles 2011); however, it is also emphasized that "the criteria for assessing industrial buildings should be defined and
Commented [a1]: Punctuation mark revised (hyphen/dash) as asked by Reviewer 3 .

Commented [a2]: Punctuation mark revised (hyphen/dash) as asked by Reviewer 3 . 
published so as to achieve general public acceptance of rational and consistent standards" (TICCIH 2003). Therefore, deriving from the theoretical framework, a set of criteria for the heritage assessment of hydroelectric plants is developed within the article. With a purpose of developing a systematic methodology in the process of conservation and restoration of hydroelectric plants, a basic guideline is prepared. The guideline consists of an explanatory text and a flowchart to be applied for various case studies. 17 case studies are selected in the Italian Alps in order to confirm the applicability of the criteria and the guideline. Following the explanation of the features and the properties of the case studies, the assessment criteria and the flowchart is applied for each case study. The process and the results of the study are discussed with an aim to serve as a model for other studies in the field of industrial heritage.

\section{Features, types and elements of hydroelectric plants:}

Hydroelectric plants of the past century have radically transformed nature to create industrial landscapes, and they have become symbols of power and intelligence in the long history of the interrelations between humankind and nature. Supplying electricity to serve the great demand for energy, they have majorly contributed to the industrialization of nations and the modernization of daily lives in the 20th century. Producing energy for industries and creating employment, they have contributed to the development of communities and social life. Moreover, as ground-breaking, inventive facilities of the period, plants and machineries installed in them reflect a significant stage in history of technology and construction.

Hydroelectric plants are basically facilities where the potential energy of water is converted into electrical energy. The flow or the fall of water from a certain height activates the turbines and the mechanical energy produced in the turbines is converted 
into electrical energy by making use of generators to be distributed for use. Hydroelectric plants and dams are categorized according to various features they possess, such as: their purposes ${ }^{1}$, their hydrological relations ${ }^{2}$, their capacities $^{3}$ (sizes), the method they use in producing electricity and their construction techniques. For the purpose of presenting a basic technical introduction of hydroelectric facilities, the last two categories will be explained briefly.

According to the method they use in the production of electricity, plants are categorized as run-of-river plants, storage plants, pumped-storage plants and off-shore plants. The type of the hydroelectric facility is determined based on the environment it is constructed in or the various demands for energy.

- Run-of-river plants: In run-of-river facilities, turbines are turned by the power of naturally flowing water to provide energy. In these cases, water is not stored and the production changes according to daily and seasonal fluctuations.

\footnotetext{
${ }^{1}$ Dams and related facilities can either be used solely for production of electricity or in some cases they can also be utilized for additional purposes, such as irrigation, flood control or supply of drinking water.

${ }^{2}$ There are cases where a single dam is constructed to produce energy; whereas in other cases a cascade of dams is built in order to constitute a connected hydro electrical system.

${ }^{3}$ The International Commission on Large Dams (ICOLD) defines a large dam as: 'dam with a height of 15 metres or greater from lowest foundation to crest or a dam between 5 metres and 15 metres impounding more than 3 million cubic metres' (ICOLD 2011a). Whereas small dams are defined as: 'a dam with a height between 2.5 meters and 15 meters above river bed level to maximum crest level and a storage volume between 2 million m3 and 200 million m3' (ICOLD 2011b).
} 
- Storage plants: In storage hydropower facilities, a dam is constructed on the river in order to create a reservoir behind it, and water is released through tunnels into turbines which activate generators for the production of electricity. At storage hydropower facilities, the system can be controlled according to the demand, and it can be operated independently for long periods of time.

- Pumped-storage plants: In pumped-storage plants, water is cycled between an upper and a lower reservoir by making use of pumps. Such plants are utilized to overcome seasonal fluctuations and changing power demands.

- Off-shore hydropower plants: As facilities of a more recent technology, offshore plants make use of tidal currents or the power of waves in order to produce electricity.

Basic elements of a storage hydroelectric plant are: the dam (structure built on a river in order to create the reservoir), the reservoir (water stored behind the dam), the spillway (Figure 1) (__-also called overflow channel___-structure for the controlled release of water, when the reservoir is full, in order to prevent damages caused by water overtopping the dam), the intake (structure for capturing water from the reservoir to be conveyed to the energy producing facilities (-Figure 2,3,4), water transfer facilities_-

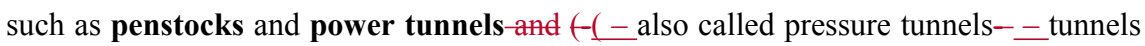
built for conveying the water, from the intake to the power house, with high pressure) and , surge tank (-(also called surge chambers--tower-like structures for reducing the pressure caused by accelerating water in power tunnels - also called surge chambers -)- 
, the powerhouse (containing turbines, generators and the control room ${ }^{4}$ ), the tailrace (structure for discharging water from the plant), the switchyard (where the electrical energy produced is stepped up to a high-voltage for transmission and distribution).

The most crucial and distinctive element of a hydroelectric plant is the dam. Dams are constructed using various methods and materials, depending on the hydrologic properties, topography, geology, climate and seismicity of the surrounding, the availability of the materials and economic conditions. The three main categories are fill dams, masonry dams and concrete dams. Fill dams (earth-fill and rock-fill dams) are embankments constructed of compacted natural materials (earth or rock), and they rely mainly on their weight to counterbalance the thrust of water. Because of their widebased triangular geometry, they are usually preferred in landscapes where the ground conditions are weak or heterogeneous and where the water level is low. There are cases where the upstream face of the embankment is covered with concrete slabs in order to provide impermeability. Masonry dams are structures built out of cut-stone or brick. Concrete dams are generally constructed of unreinforced blocks of concrete with flexible seals at the joints. Different types of masonry dams and concrete dams, according to their construction techniques, are gravity dams, buttress dams and arch dams. Gravity dams are structures which depend on their weights in order to resist the power of water acting on them. Therefore, they require strong ground conditions and well-designed foundations. Buttress dams also work with the same principle, except for the fact that in a buttress dam, the concrete slab is thinner and it is supported by a series

\footnotetext{
${ }^{4}$ Turbines convert the kinetic energy of water into mechanical energy, and the generators convert the mechanical energy into electrical energy. The whole process is conducted in the control room of the powerhouse.
} 
of buttresses on the downstream side. Arch dams are curved structures with the top of the arch facing upstream so that the pressure of water compresses the structure which transfers the load to the sides of the valley through its abutments and to its foundation. Arch dams are constructed at narrow valleys where the sides of the canyon are stable and stiff. In many cases, arch dams are double-curvature structures, curved on horizontal and vertical planes similar to a section of a sphere (Figure 5). There are also cases __ such as arch-gravity dams___ where a combination of techniques is implemented.

Hydroelectric plants, constructed with great investments and major interventions in nature, have been designed and designated for long-term service; however, as is true with all beings, their life-spans are limited, and they require periodic and constant inspection and sustainable maintenance. In most cases, the removal of a hydroelectric facility is more expensive and technically more difficult than preserving or restoring it. Moreover, since they are human-made structures constructed against the overwhelming power of nature, abandoning dams, unmonitored and unattended, creates a major risk of disaster. Therefore, it is crucial to make provisions for the future of hydroelectric plants, to specify criteria for their assessment, and to develop guidelines for their conservation.

\section{Assessment criteria for hydroelectric plants as industrial heritage:}

Based on the continuing presence of human-built structures for thousands of years, it can be concluded that 'the idea of preservation' is also rooted in millennia. Throughout history, several opinions have been developed on questions regarding which structures to preserve and how they should be preserved. Alois Riegl, in his work "The Modern_Cult_of Monuments: Its Character and Its Origin (1903)," has suggested one of the pioneering systematic methods for the value assessment of monuments; discussing
Commented [a5]: Punctuation mark revised (hyphen/dash) as asked by Reviewer 3 .
Commented [a6]: Punctuation marks are revised as asked by Reviewer 3 . 
'the past values' under main categories of 'commemorative value,' 'historic value' and 'age value.' Nevertheless, within over two-hundred years, even the description and context of cultural property has evolved, necessitating exclusive and more detailed studies on various types of heritage. In this context, national or international working groups of specialists and experts have been developing principles for the preservation and conservation of different types and aspects of cultural heritage.

Concerns regarding the conservation of industrial heritage arose by the end of the 19th century and the intellectual approach was shaped during the 20th century. The concept of 'industrial archaeology' was initially used by Michael Rix in 1955 in his influential article in 'Amateur Historian' (Rix 1955). The International Committee for the Conservation of the Industrial Heritage (TICCIH) was established in 1973, and published 'The Nizhny Tagil Charter for the Industrial Heritage' in 2003. In the document, industrial heritage is defined as: "the remains of industrial culture which are of historical, technological, social, architectural or scientific value. These remains consist of buildings and machinery, workshops, mills and factories, mines and sites for processing and refining, warehouses and stores, places where energy is generated, transmitted and used, transport and all its infrastructure, as well as places used for social activities related to industry such as housing, religious worship or education." Within the document, TICCIH develops the general framework for the value assessment of industrial heritage and has emphasizes that:

- "The industrial heritage is the evidence of activities which had and continue to have profound historical consequences. The motives for protecting the industrial heritage are based on the universal value of this evidence, rather than on the singularity of unique sites.

- The industrial heritage is of social value as part of the record of the lives of ordinary men and women, and as such it provides an important sense of identity. It is of technological and scientific value in the history of 
ICOMOS (International Council on Monuments and Sites) has adopted the Joint ICOMOS - TICCIH Principles for the Conservation of Industrial Heritage Sites, Structures, Areas and Landscapes, also called "The Dublin Principles." 'The Dublin Principles' document defines industrial heritage as: "sites, structures, complexes, areas and landscapes as well as the related machinery, objects or documents that provide evidence of past or on-going industrial processes of production, the extraction of raw materials, their transformation into goods, and the related energy and transport infrastructures" (Dublin Principles, 2011). Although the definition is similar to that of The Nizhny Tagil Charter, 'The Dublin Principles' document adds the concepts of 'sites,' 'landscapes' and 'documents' in the definition. Addition of 'sites' and 'landscapes' emphasizes the profound connection between the cultural and natural environment, and the concept of 'documents' underlines the movable and intangible aspects of industrial heritage. Both documents express the requirement for the specification of criteria for the assessment and conservation of various types of industrial heritage.

Industrial heritage is generally categorized and evaluated according to the type of production conducted in the facilities. Michael Falser also utilized such a method in his report "Is Industrial Heritage Under-Represented in the World Heritage List" for 
UNESCO World Heritage Centre in 2001. However, specific descriptions and criteria for different types of industries still remain to be developed.

Countries utilize their national charters and legislations for the assessment of hydroelectric plants. For example, in Australia, the criteria used for the assessment of hydroelectric facilities are: 'historical significance,' 'associative significance,' 'aesthetic significance,' 'social significance,' 'research potential,' 'rarity,' 'representativeness' and 'integrity' (NSW 2008).

In the USA, besides the United States National Register Criteria for Evaluation, one of the states (Vermont) has developed a set of 'value categories' to better determine the relative importance of one 'significant' dam over another 'significant' dam. The criteria suggested are:

- "How long a dam has been at a particular location;

- The extent to which a historic environment still exists around a dam site (e.g. buildings or archaeological remains that are part of the original community);

- The extent to which features directly associated with the historical function of a dam remain present to illustrate what the dam was for and how it worked (e.g. mill buildings, canals, etc.);

- Intrinsic physical characteristics of a dam as it exists today to determine whether it might represent a particularly unusual type of dam or might be important in the history of dams and engineering;

- The age of an existing dam in relation to the time period it was built (e.g. the earlier a dam was built within the period of that type of construction may have greater value);

- The extent to which a dam possesses historical integrity - meaning the degree to which the original design, workmanship and material of the dam remains" (Mcclain, Lindloff, and Baer 2008).

Within the study, the assessment criteria for industrial heritage are investigated over hydroelectric plants in the context of the theoretical framework explained above. It is 
culturally important to preserve these structures, as proofs of extraordinary human intellectual power, which have witnessed a breakthrough in the history of technology. Moreover, the specification of criteria for hydroelectric plants is crucial also for safety reasons, because inappropriately designed or poorly maintained plants and dams create a major threat for nature and human life. Therefore, the criteria have been specified as a result of consultations with civil engineers, electrical engineers, geologists, hydrologists and ecologists in correspondence with principles of an interdisciplinary study. In the context of this study, the criteria for the assessment of hydroelectric plants and dams have been specified as:

- Age value and historic value: Dams and hydroelectric plants which have become integrated with their surroundings after a long period of existing in their landscapes have gained cultural value. They have transformed the nature into industrial landscapes, while creating social communities. They represent a major breakthrough in the history of the interaction between humankind and nature. Moreover, hydropower facilities as witnesses and evidences regarding the processes of energy politics in each country, along with cases which are related with significant events and people in history should be considered in this category.

- Technological value: Hydropower facilities of the 20th century are reflections of changes in technology. Along with the developments in construction technologies and techniques in energy production, they represent the processes of human intelligence and power. Besides the construction of dams which were products of the high-technology in the civil engineering of the period, elements and machinery which are currently dysfunctional because of the changing 
technologies in modern plants are important for educational purposes of technological history.

- Architectural / artistic value: Hydroelectric plants presenting special design properties and facilities which include products of fine arts (frescoes, paintings, sculptures etc.) are examined in this category, along with plants that reflect the significant design techniques and architectural styles of the past.

- Integrity: As a result of the developing technology throughout the life-span of facilities, one of the major problems in the conservation of industrial heritage is the loss of physical and functional integrity through the change and upgrade of elements and machinery. In case of hydroelectric plants, constructive elements such as dams, intake structures, water transfer facilities and outlets are usually preserved, since they are difficult and expensive to remove. However, machinery such as turbines, generators, alternators and control room devices are significant in terms of the authentic physical and functional integrity of the facilities.

- Social and economic value: Hydroelectric plants which have created communities and enriched social life by providing employment are important in terms of memories and attachment to the facilities. They present an identity by reflecting the lives of ordinary people, the workers of the past. The continuation in the function of the plant and/or the presence of the social community, socially and economically, enhances and assists the preservation of the plant. Besides, in many cases, reservoirs created by hydroelectric plants constitute recreational areas for fishing and touristic attractions as contemporary social and economic value. 
- Environmental and/or structural safety: In some cases the presence of a dam creates a threat for the environment. The removal of dams altering natural habitats and causing the extinction of species is a controversial issue on the agenda. Moreover, inadequately designed dams or facilities deteriorated as a result of inappropriate monitoring cause catastrophes resulting in the loss of lives. Under specific conditions where hydroelectric plants irreversibly damage natural habitats or in case of deteriorated dams creating risks of failure and collapse, the removal of the facilities are required. The decision regarding the removal of hydroelectric plants should be made through an extensive interdisciplinary inspection and investigation with the collaboration of related experts. Regarding the facilities which are decided to be preserved, measures should be taken; periodic maintenance and monitoring should be provided for environmental and structural safety.

\section{Guideline and flowchart for the conservation of hydroelectric plants:}

Deriving from the principles suggested in the Nizhny Tagil Charter and Dublin Principles, a general framework of the guidelines is prepared for the conservation of hydroelectric plants. The guideline is designed as a flowchart with basic principles included (Figure 6). The flowchart starts with the identification of the plant as industrial heritage, and continues with yes/no questions to determine the structural and environmental status of the facility. After the decision for the conservation / preservation of the site, the flowchart continues in order to determine the function or possible adaptive re-use of the plant, and assists in the management of the plant by referring to fundamental principles. The flowchart is an easy tool to apply, since it develops the general framework; however, in case of an intervention to a plant, it is 
highly critical that the utilization of the flowchart should be confirmed with an extensive and detailed interdisciplinary study of the hydroelectric plant and a thorough evaluation of the principles stated below:

- Hydroelectric plants with cultural values should be identified and recorded; easily searchable and freely accessible inventories should be created for the interest of researchers. It is important to create a database of the inventory and to keep it up to date by periodically including the contemporary physical properties and conditions of each facility. The inventory and database should include descriptions, drawings, photographs and movies of the plants, along with the recordings of the communities' and people's memories related with the facilities.

- A thorough investigation should be conducted about the original structure and all former components and machinery. Since most of the structural components of hydroelectric plants -_such as dams, intake structures, power tunnels, etc. - are buried in nature, upgrading and removal of elements of these facilities are rarely observed. However, machinery in the power houses, such as turbines, generators, alternators or switches, might have been upgraded in the course of time, or the power houses might have been enlarged for the addition of new turbines with the increasing demand for energy. It is required to investigate the processes throughout history and to document them for new generations with utmost elaboration.

- The physical and functional integrity of the hydroelectric plant should be preserved, and the plant __ including all the machinery and components

Commented [a10]: Punctuation mark revised (hyphen/dash) a asked by Reviewer 3 . should be conserved in situ. Hydroelectric facilities are industrial sites anchored in their natural surroundings, creating a new artificial nature in the landscape. 
In case of re-functioning, the integrity of the whole site must be considered for the new function. Adaptive re-use of power houses is comparatively easy when compared to dams, since power houses are merely shells covering the machinery for the production of electricity. However, dams __as the primary constructive element of hydroelectric plants-- are more difficult to re-function, because of their locations in nature and their variable forms and geometries. The unique geometry, type and location of each dam require a distinct design for the new use, and it is possible to develop creative designs using the slope or the curve of the structure.

Commented [a11]: Punctuation mark revised (hyphen/dash) as asked by Reviewer 3 . 
In case of adaptive re-use, there are certain issues to consider in the selection and organization of the new function of a hydroelectric plant:

- As stated in the Nizhny Tagil Charter: "New uses should respect the significant material and maintain original patterns of circulation and activity, and should be compatible as much as possible with the original or principal use" (TICCIH 2003). It is not acceptable to remove the authentic elements and machinery or to interrupt the integrity of the site in order to meet the requirements of the new function. Functions related with the original purpose of energy production and contributing to education and culture should be prioritized. In this context, initial options might be energy museums, training /recreation camps for employees/workers in the production of electricity, departments of technical schools or universities related to electricity production, etc. On the other hand,-- provided that the integrity and the authenticity of the space is respectedexhibition halls, in-door and out-door art galleries, performance centres and other creative hubs which require large spaces and possess spatial flexibility are among possible suggestions for the re-use of hydroelectric facilities.

- Elements and components of the hydroelectric plant may contain patina. Patina is integral to the cultural property, and it should not be removed. Health and safety measures should be taken, and the new function should be arranged and organized respecting the elements, components and machinery with patina.

- Interventions should be reversible and should have a minimum impact on the heritage. Any unavoidable intervention should be elaborately documented, and any authentic parts or machineries which are removed for extraordinary reasons should be stored safely; they should be kept open to the public either at or near 
the site. Informative panels describing the features and the history of the plant should be presented at the site.

- Interest and involvement of public is one of the driving forces in the conservation of industrial heritage. Therefore, organizing events, exhibitions and different forms of communications on TV, Internet and other media, providing managed public access to energy facilities and promoting tourism in industrial sites by creating connections with cultural and natural touristic routes are methods which can be utilized.

\section{Case studies of dams and hydroelectric plants in Italy:}

As huge structures of engineering grow older, it is required for new generations to find solutions for safety and preservation. The issue of conservation and maintenance of ageing infrastructures such as roads, highways, bridges and dams have gained crucial importance in Italy, especially after the collapse of the Morandin Bridge in Genoa on August 14, 2018. According to a report published in 2018, there are 533 large dams (more than $15 \mathrm{~m}$ high or with a reservoir exceeding $1000000 \mathrm{~m}^{3}$ ) in Italy by March 2018 (Facchini 2018). It is also reported that 382 of these dams are currently active; 32 are in limited operation for technical reasons; 81 in experimental operation; 11 under construction; 27 out of operation. $61 \%$ of the dams are utilized for hydroelectric purposes. Within the report, the average age of the current dams in Italy is calculated to be 62 , which means that a great majority of the present dams are structures of the past century in need of extensive care.

The initial hydropower facilities in the Italian landscape have been consolidated through a long time, and their impact on the environment has already been acknowledged, with new values being currently assigned to these places. These are 
values are related to historical, technological, artistic / architectural, economic, social and environmental knowledge and awareness. Although initially the debate on hydropower landscapes was subject to the strong opposition condemning the role of industry in the destruction of the Italian natural landscape, it has come to a general conclusion that historical facilities of hydropower___ where the artificial nature and architecture become components of evidence for cultural development with their striking effects on the environment-- - also offer a territory of protection in terms of the knowledge of science and technology (Bossum 2015). Contemporarily, bicycle and walking routes and paths are created along water canals; historical power houses are being converted to cultural spaces; 'open-plants days' are organized for free visits to hydropower facilities; videos, photographs of hydroelectric systems are exhibited; books and other written documents are being published for the interest of the public.

In Italy, the pioneering publications regarding the issue are "Le Dighe di Ritenuta degli Impianti Idroelettrici Italiani," published in 1961 by ANIDEL (Associazione Nazionale Imprese Produttrici e Distributrici di Energia Elettrica / National Association of Producers and Distributors of Electricity) and "Le Dighe di Ritenuta degli Impianti Idroelettrici Italiani / Dighe Appartenti all'Enel di Costruzione Posteriore al 1953," published in 1974 by ENEL (Ente Nazionale per l'Energia Elettrica). Within the 7 volumes of the book, ANIDEL gives a detailed documentation of the dams in Italy by the end of 1959. ENEL (an Italian energy company) continues the documentation with 6 volumes in 1974, introducing the technical features of the 70 facilities in its property. Another rich source of data is the web-site "Progetto Dighe (www.progettodighe.it)" where researchers have joined to share information on Italian dams.
Commented [a13]: Punctuation mark revised (hyphen/dash) as asked by Reviewer 3 . 
In the broader context of the study, numerous examples of hydroelectric plants from different countries of the world are examined, a database of all the Italian dams introduced in the above-mentioned sources is prepared. From within the database, representative case studies in the Italian Alps are selected to be presented in the article. In the region, rivers run in deep, narrow valleys, and the hydropower facilities are interconnected with each other, creating 'hydroelectric systems.' Since they comprise case studies of different periods, presenting a variety of construction techniques and a diversity of functions, The Hydroelectric System of the Upper Chiese River (Ponte Murandin Dam, Boazzo Dam, Bissina Dam, Boazzo Power House, Cimego Power House), The Hydroelectric System of Piave-Boite-Vajont (Pieve di Cadore Dam, Valle di Cadore Dam, Val Gallina Dam, Vajont Dam, Achille Gaggia / Soverzene Power House, Perarolo Power House) and The Hydroelectric System of the Middle and Lower Cellina (Barcis Dam, Cellina / Old Barcis Dam, Barcis Power House, Antonio Pitter / Malnisio Plant) are selected as the main routes of the study. However, additional case studies in the vicinity are also included in order to enrich the research with various interesting cases of hydroelectricity (Fies Plant, Taccani Plant).

\subsection{Technical features of the case studies:}

Although the facilities of energy production are interconnected as hydro-electrical systems, the elements of dams and power houses possess different characteristics. Therefore, the case studies are categorized as dams and powerhouses with special emphasis on their interconnections. In the broader context of the study, other elements such as intake structures, outlets and water transfer facilities are also investigated, but dams and power houses ${ }_{-}$as more distinctive elements of hydroelectric plants-__ are examined in the article. Dams are examined in terms of their construction periods, 
types, geometrical and geographical features. Photographs taken during the construction of each dam is provided from ANIDEL and ENEL and they are presented at Table 1 along with the current photographs taken by the authors in 2019 .

In the documentation of ANIDEL (1961), it is reported that among the total of 348 dams in Italy in 1959, 213 are higher than $30 \mathrm{~m}$. Out of the 213 dams, 167 were being utilized for hydroelectric purposes; 21 for multiple purposes including hydroelectricity; 25 for other purposes such as irrigation, flood prevention and the supply of drinking water. Regarding the construction techniques of the 213 dams, it is reported that 31 were gravity dams in masonry; 58 in concrete gravity; 21 in cellular gravity; 7 with multiple arches or buttresses; 22 in arch-gravity; 53 arched; 6 in dry stone masonry; 2 in rock-fill; 10 in earth-fill and 3 in concrete blocks (ANIDEL, 1961). Within the 213 dams, 4 were constructed before 1889, 1 was constructed in the $1890 \mathrm{~s} ; 4$ were constructed in the 1900s; 9 were constructed in the 1910s; 41 were constructed in the 1920s; 34 were constructed in the 1930s; 23 were constructed in the 1940 s; 97 were constructed in the 1950 s.

In the context of the article, all of the case studies of dams for hydroelectric purposes have crest heights over $30 \mathrm{~m}$. 1 case study (Old Barcis / Cellina) is a gravity dam in masonry, 2 case studies (Boazzo and Bissina) are cellular gravity dams, 2 case studies (Ponte Murandin and Pieve di Cadore) in arch-gravity, 4 case studies (Barcis, Val Gallina, Valle di Cadore and Vajont) are concrete double-curvature dams. 1 of the dams (Old Barcis / Cellina) was constructed in the 1900s, whereas the construction of 3 dams (Valle di Cadore, Pieve di Cadore and Val Gallina) started in the 1940s and 5 dams (Ponte Murandin, Boazzo, Bissina, Barcis and Vajont) were constructed in the 1950s. 
Hydroelectric plants in Italy before the 20th century were basically improved versions of old mills, in the sense that they depended on the natural course of water. They would utilize the power of water and release it to the natural stream. However, by the 20th century, increasing demand for energy required more complex facilities. Seasonal fluctuations in river courses and storage of energy were crucial problems to overcome. Therefore, large reservoirs were created at high altitudes with new plants radically altering the geography of landscapes. At the beginning of the 20th century, the power houses usually consisted of two main bodies: the engine room and the transformers cabin (Menini 2013). The engine room is a large hall where the turbines are installed. The power tunnels from the slope of the mountain reach the basement of the engine room to feed the turbines. The surrounding space in the engine room, also housing a bridge crane, is generally bright with several windows. The transformers cabin is a unit -_ usually consisting of two floors-_-adjacent to the engine room. Heavy transformers were installed on the ground floor, whereas the upper floor was occupied by switches, lines and other devices for energy distribution. After the Second World War, hydroelectric plants underwent a radical change. The power houses started to be constructed in caves within the bodies of mountains. Transformers continued to be installed in the buildings, but the network of switches have become so complicated that they had to be placed outside the buildings to create the switchyards (Menini 2013).

Case studies of power houses are examined in terms of their construction periods, machinery and other particular features, and they are presented at Table 2 along with their current photographs taken by the authors in 2019. 3 of the plants (Taccani, Antonio Pitter and Fies) were built in the 1900s, Perarolo Plant was constructed in 1949, and the rest of the power houses (Cimego, Boazzo, Achille Gaggia and Barcis) 
were built in the 1950s. Achille Gaggia and Barcis powerhouses were constructed within caves.

\subsection{Assessment of the case studies in terms of industrial heritage criteria:}

The selected case studies are assessed in terms of the criteria of industrial heritage defined within the study; a mapping of the assessment_-_depicting the superposition of criteria-_ _ and a table defining the assessment of each case study is presented in Figure

7. The assessment of each criterion includes varying aspects related to the diversity of case studies. All of the selected examples have age value / historical value, and technological value, since they are the initial criteria used for the selection of case studies. Within the seventeen cases, 7 examples (41\%) have an exceptional architectural / artistic value; 15 cases (88\%) still possess integrity; 15 of them (88\%) currently present a social/economic value; through an external observation, 14 of them (82\%) appear to be structurally and environmentally safe. The three case studies, which appear to be lacking safety, are also missing integrity and social/economic value since they are out of use -except for Vajont Dam with a specific social value which will be explained in the following paragraphs. The percentages of the results verify that the functioning or re-functioning of hydroelectric plants also supports the sustainability of cultural features of industrial heritage.

- Age value / historical value: All of the selected case studies have age value, since they have all been constructed more than 50 years ago, and they have been integrated with their environment to create new surroundings of the past. Each example represents the interrelations of humankind and nature in the 20th century, signifying a breakthrough in engineering technology. Among the case studies, Vajont Dam has an extraordinary historical significance, because of a 
disaster on 9 October 1963. Construction of the dam and the reservoir resulted in the weakening of the land surrounding the reservoir basin, and a massive landslide occurred causing a giant wave which overtopped the dam, destroying several villages and resulting in 1917 deaths. Because of its relationship with the significant event in history, Vajont Dam has a tragic but special value in terms of historical assessment.

- Technological value: All of the examined case studies have technological value, because they are pioneering examples of civil engineering in the periods they were constructed. The struggle of humankind, for the production of energy, resulted in innovative technologies for the construction of dams to contain and capture tons of water. Especially Boazzo Dam and Bissina Dam are significant because of their special construction technique developed by their designer, Claudio Marcello. They were constructed in a cellular gravity method-_which is also called 'Marcello type' (-derived from the name of the engineer Claudio Marcello) (Figure 8). Case studies also include power houses which possess technological value because of the authentic machinery installed in them.

- Architectural / artistic value: Hydroelectric plants designed in the early decades of the 20th century, generally followed the styles of the past in a traditional, monumental character (Menini 2013). Taccani, Fies and Antonio Pitter plants, virtually resembling historic castles, are examples of the earlier plants designed in a traditional approach. However, after the Second World War, a revolution has taken place in the design of the plants, completely changing the image and the configuration of the power houses. Rather than establishing continuity with the landscape and pursuing a connection with the traditional styles, the new plants of the 20th century, became contemporary structures 
symbolizing the intervention of humankind transforming the territory, and the power houses, after the Second World War, such as Achille Gaggia and Barcis power houses, were built in caves inside the mountains. These plants (Taccani, Fies, Antonio Pitter, Achille Gaggia and Barcis Plants), each representing the architectural styles of their period, have architectural values. Another exceptional case of architectural / artistic value is the vault of the engine room in Achille Gaggia Power House which has frescoes by Walter Resentara, on the theme of electricity. Boazzo Dam and Bissina Dam are also specified to have architectural value because of their special design by Claudio Marcello -as explained before.

- Integrity: The criterion of integrity signifies structural integrity as well as integrity of the industrial complex with all the authentic elements and machinery. Most of the case studies have structural integrity except for the two cases of Vajont Dam and Perarrolo Power House. Perarolo Power House was constructed in 1949 in order to produce energy utilizing Valle di Cadore Dam and the related facilities; however, Perarolo Power House was abandoned, only a few years after its construction, with the construction of Achille Gaggia (Soverzene) Plant in 1951. Currently, the Perarolo Power House is in poor structural condition, without any machinery or any function. As explained before, Vajont Dam has caused a disaster, flooding several settlements in 1963. The basin was filled with the material accumulated as a result of the massive landslide, and the flooding water has overtopped the dam; however, after the great disaster, the dam is still intact at the site. Nevertheless, the river does not run by the dam and the reservoir does not exist anymore. Therefore, Vajont Dam lacks contextual integrity (Figure 9). The aspect of integrity is also questionable 
in the case studies of Antonio Pitter and Fies Plants. Antonio Pitter Power House was closed in 1988, and it remained out of service for many years until 2006, when it was restored and reopened as a museum of hydroelectricity. Currently, the plant is intact and although it does not produce energy anymore, in the engine room it houses many authentic turbines along with various kinds of machinery brought from other plants. Similarly, Fies Plant was closed in 1961, and it was abandoned for many years, until its restoration at the beginning of 2000 s as a centre for contemporary art. A relatively small part of the plant still functions for energy production, but most of the components and machinery in the art galleries had been lost during the years of abandonment. Despite the partial loss of integrity, adaptive reuses of the two plants have enabled the sustainability of the plants without any further damage.

- Social and economic value: Hydroelectric plants of the 20th century have created a major social and economic impact in their neighbourhoods. This is confirmed by events such as exhibitions, meetings and movies prepared about various facilities of hydroelectricity in Italy. For example 5 of the case studies (at the Upper Chiese System) in Trentino have been the subject of cultural events in the recent past: a documentary movie called "Gli Uomini della Luce: Storie di Centrali Idroelettriche in Trentino [The Men of the Light: History of Hydroelectric Plants in Trentino" was made by Katia Bernardi in 2011, and in February 2018, an exhibition was held in Trentino about the history of the main hydroelectric plants of the region. Such events should be recorded and documented for public share; otherwise, it is difficult to reach their contents after the activity is over. The most apparent aspect of social and economic value is the continuation of function. Most of the case studies are still active in energy 
production, generating a socio-economic value. Among the case studies,

Antonio Pitter and Fies Plants represent special cases, since they generate a new social environment as a result of their current new functions. Taccani Plant is also exceptional as a case study because of its relationship with Crespi d'Adda (registered in the World Heritage List of UNESCO). However, two case studies, Perarolo power house and Cellina Dam, have lost their functions and they remain obsolete at their sites.

- Environmental and/or structural safety: In Italy, there are not many cases where environmental concerns contradict the presence of hydroelectric facilities; therefore none of the case studies appears to be a threat on the environment. Most of the case studies are still active and they are monitored and managed for structural deficiencies. However, extensive and periodic inspections should be constituted for the structural safety of Cellina Dam, Perarolo power house and Vajont Dam which are currently inactive. The assessments of structural safety of all case studies were realized only through an external observation; therefore, they are not valid for any further decision or intervention; extensive and detailed inspection of each hydroelectric plant is required for any further action.

\subsection{Current statuses of the case studies and application of the flowchart:}

Considering the heritage assessment, the flowchart is applied for each case study, with a purpose of determining its current status and potentialities for its conservation (Figure 910). All of the 17 case studies have the properties of cultural heritage, as explained before. Regarding the question of structural safety, 14 of the case studies appear to be structurally safe as they are currently being managed and maintained. However, for the cases of Vajont Dam, Cellina Dam and Perarolo Power House, which are abandoned 
and out of function, structural safety is an issue to be examined in detail with the consultancy of engineers. Therefore, they are currently in the second step of the flowchart. After extensive studies on structural safety, it should be decided whether to remove the structures or to preserve and re-function them, and the proceeding steps of the flowchart should be implemented accordingly. However, among these cases, Vajont Dam presents an extraordinary importance. Because of its historical value associated with the disaster and the loss of lives, beyond its presence and sustainability as a power plant, the preservation of Vajont Dam should also regard the memories of people, and the structure should be preserved as a memorial site.

Since none of the case studies create an environmental threat, 14 of the case studies are subject to conservation and preservation procedures. Antonio Pitter Power House had lost its original function in 1988, and after years of abandonment it was not possible to use the power house with its original function. Therefore, a new function had to be assigned for the plant which is located near Montereale Valcellina. It was decided to re-function the power house as a museum of hydroelectricity, which also exhibits the original elements of various hydroelectric plants in the region. The museum is on a bicycle / walking route along the canal, and it attracts the attention of people in the region, especially with the Malnisio Science Festival organized every year. Although the plant is not currently functioning for energy production, the intervention for the new function is noteworthy because the original machinery is exhibited in the engine room, where it belongs, and all the spaces of the building are legible in correspondence with the original configuration.

Centrale Fies was closed in 1961, and most of the machinery was lost during the years of abandonment. However, it was possible to produce electricity in a small part of the plant. Cultural events started in the region with Drodesera Festival in the 1980s, and 
cultural events played a major role in the evolution of the site to a contemporary art center at the beginning of 2000s. The plant is situated near Dro, a town near Sarca Valley, and it attracts important artists from different parts of the world. Within the site, accommodation facilities are present for artists and curators of the exhibitions. Although they occupy the same building, the power generating part and the exhibition halls function independently. In the exhibition halls, it is possible to observe the locations of the technical elements which are not present anymore.

Bissina Dam still functions for containing water in Lago di Malga Bissina and Pieve di Cadore Dam continues to hold back the waters of Lago di Cadore; however, their function is not limited to hydroelectrical purposes. They also represent interesting examples in terms of an alternative approach to dams. Bissina Dam has been the location of an international climbing competition organized every year between 2001 and 2013. There are two routes for the competitors of "Speed Rock," to climb the 84 meter high dam. The organization attracted interest of athletes from different countries of the world, and resulted in some camping and recreational facilities in the vicinity. Although the dam is far from city centres, it is possible to reach the site by car or by bicycling in the impressive nature of the Alps. Pieve di Cadore Dam also hosts climbing activities since 2002 .

10 of the case studies (Boazzo Dam, Ponte Murandin Dam, Val Gallina Dam, Valle di Cadore Dam, Barcis Dam, Cimego Powerhouse, Boazzo Powerhouse, Barcis Powerhouse, Achille Gaggia Powerhouse and Taccani Plant) still function with their original purposes. Among these case studies, Taccani Plant-_-because it is related with a site registered in the World Heritage List (Crespi d'Adda)-) - is special, and it attracts attention of school groups and enthusiasts of industrial heritage and nature. For the case Conted [a20]: Punctuation mark revised (hyphen/dash) as attention of school groups and enthusiasts of industrial heritage and nature. For the case studies sustaining their original function, periodical maintenance and monitoring of the 
site is an essential requirement. It is important to document and record the status of the plant periodically in order to create an accessible inventory and it is also suggested to develop methods to create and support public awareness regarding the cultural features of the plant as industrial heritage.

\section{Conclusion:}

The competent management of cultural heritage requires thorough knowledge and evaluation of the subject, causality-_-_with a strong theoretical background and a targetoriented assessment perspective,$-\ldots$, and a methodological and applicable approach of intervention. As emphasized within 'the 7 Theses of Monuments' of the Municipal Building Commission of Utrecht, "respecting cultural history is not possible without public support" and "losing the historical context is generally not due to unwillingness, but rather to a lack of knowledge" (Hain, Löffler and Zajicek 2016). Deriving from this perspective, the article discusses hydroelectric plants of the 20th century as industrial heritage, introducing their significant features and properties; investigates criteria for the heritage assessment of these facilities; and develops a guideline for their processes of conservation and/or restoration. The study is structured in a comprehensive and clear methodology, aiming not only specialists of the field - but also the public - as a target group, in order to develop public awareness. Through the investigation of criteria and the guidelines, it is expected to build knowledge regarding hydroelectric plants as industrial heritage for the use of experts and specialists (architects, engineers, ecologists, etc.), local authorities and investors and to develop a sound basis for the consideration and inclusion of these facilities in the legal framework of conservation in each locality. In the initial and broader context of the study, the criteria and principles were developed through the examination of numerous examples from different parts of
Commented [a21]: Punctuation mark revised (hyphen/dash) as asked by Reviewer 3 .

Commented [a22]: A study of 'the 7 Theses of Monuments' is suggested by Reviewer 2. A direct reference (a detailed documentation of the original work) could not be provided. Therefore an article by Vladimir Hain et al is presented here as a secondary reference.

Commented [a23]: Specification of the target group was asked by Reviewer 2 .

Enhancement of the accuracy of the proposal was suggested by Reviewer 3 in order to improve the conclusion. 
the world; however, for a more consistent focus, the case studies have been limited to 17 examples in Northern Italy. In order to inspect their validity and applicability, the assessment criteria and the guidelines have been applied for the 17 case studies.

Since the article solely aims to constitute a general framework, examinations of all the case studies are based on external observations and on-site investigations. However, each case of heritage management requires a specific and detailed study of the subject. Therefore, neither the criteria specified, nor the flowchart present absolute and conclusive results about the case studies. They are merely proposed as applicable tools of an approach to industrial heritage, aiming to constitute the initial steps of more extensive and detailed interdisciplinary studies on the preservation and conservation of each specific hydroelectric plant.

Both the assessment criteria and the flowchart are valid only for the period when they are applied for each case study. In case of passing time or changing conditions, they should be re-applied for the new circumstances. For example, if a currently active hydroelectric plant deteriorates, loses its function, integrity or structural stability, the assessment should be started from the beginning, and each step should be followed accordingly with the consultancies of experts in an interdisciplinary context.

Within this study, realized in 2019, it is observed that almost all of the case studies which have lost their original functions are facilities dating back to the early decades of the 20th century (Antonio Pitter Plant, Cellina Dam, Fies Plant). Plants constructed in mid-century are still active, continuing to produce energy (except for the extraordinary cases of Vajont Dam and Perarolo Powerhouse). However, it is predictable that in the near future, as a natural result of ageing and decay, the plants of the mid-20th century will also be requiring emergent strategies for their conservation. 
Therefore, the study aims to serve as an initial model for further studies on the preservation, conservation and restoration of these facilities.

Acknowlegment: This article is an output of a research project supported by the Scientific and Technological Research Council of Turkey (TÜBİTAK) under Grant 2219 (International Postdoctoral Research Fellowship Programme).

Declaration of interest: It is confirmed that there are no conflicts of interest to disclose.

\section{References:}

ANIDEL (Associazione Nazionale Imprese Produttrici e Distributrici di Energia Elettrica / National Association of Producers and Distributors of Electricity) 1961. Le dighe di ritenuta degli impianti idroelettrici italiani [The dams of Italian hydroelectric plants]. Rome / Italy: ANIDEL.

Bossum, E. 2015. Valorisation et interprétation du patrimoine hydroélectrique dans le paysage contemporain en Italie [Valorization and interpretation of the hydroelectric heritage in the contemporary landscape in Italy]. e-Phaistos, IV-2, 60-70.

Dublin Principles. 2011. Joint ICOMOS-TICCIH Principles for the conservation of industrial heritage sites, structures, areas and landscapes. Dublin, November 28, 2011.

ENEL (Ente Nazionale per l'Energia Elettrica) 1974. Le dighe di ritenuta degli impianti idroelettrici italiani: Dighe appartenti all'Enel di costruzione posteriore al 1953 [The dams of Italian hydroelectric plants: Dams belonging to Enel built after 1953]. Rome / Italy: ENEL.

Facchini, D. 2018. L'Italia ai piedi delle grandi dighe: Tra vetustà, sicurezza e future [Italy at the feet of large dams: Between age, security and future]. Altreconomia, December 2018. Accessed August 8, 2019. https://altreconomia.it/futuro-grandidighe/

Falser, M. 2001. Is industrial heritage under-represented in the World Heritage List, report for UNESCO World Heritage Centre, Austria. Accessed August 8, 2019. https://whc.unesco.org/archive/ind-study01.pdf 
Hain V. , R. Löffler and V. Zajicek. 2016. Interdisciplinary cooperation in the virtual presentation of industrial heritage development. Procedia engineering 161 (2016), 2030-2035.

ICOLD (International Commission on Large Dams). 2011a. Constitution statuts. Paris, July 2011. Accessed August 8, 2019. https://www.icoldcigb.org/userfiles/files/CIGB/INSTITUTIONAL_FILES/Constitution2011.pdf.

ICOLD (International Commission on Large Dams). 2011b. Small dams: Design, surveillance and rehabilitation. Accessed August 8, 2019. http://www.cbdb.org.br/bulletins/icold-small-dams-sept-2011.pdf

Jappelli R. 2005. Monumental dams. In Mechanical modelling and computational issues in civil engineering, ed. M. Frémond and F. Maceri, 1-102. Lecture notes in applied and computational mechanics, vol 23. Berlin: Springer.

Mcclain, S., S. Lindloff, and K. Baer. 2008. Dam removal and historic preservation: Reconciling dual objectives. Washington DC / USA: American Rivers.

Menini, G. 2013. L'architetture del "carbone bianco" [The architecture of the "white coal"']. In I luoghi dell'acqua: Architetture e paessagi delle centrali elettriche in Valtellina [The places of water: Architecture and landscape of hydroelectric plants in Valtellina], ed. G. Menini. Sondrio / Italy: Credito Valtellinese.

NSW (NSW Government Office of Environment and Heritage). 2008. Nymboida Hydro-electric Power Station Complex. Accessed August 8, 2019. https://www.environment.nsw.gov.au/heritageapp/ViewHeritageItemDetails.asp $\mathrm{x}$ ?ID $=3110013$

Riegl, A. 1903. The modern cult of monuments: Its character and its origin. Trans. K. W. Forster and D. Ghirardo, Oppositions, n. 25 (Fall 1982), 21-51.

Rix, M. 1955. Industrial archaeology. Amateur historian, v.2 n.8 (October-November 1955), 225-229.

TICCIH (The International Committee for the Conservation of the Industrial Heritage). 2003. The Nizhny Tagil Charter for the industrial heritage. Moscow, July 17, 2003
Commented [a24]: New reference added after the suggestion of Reviewer 2. 


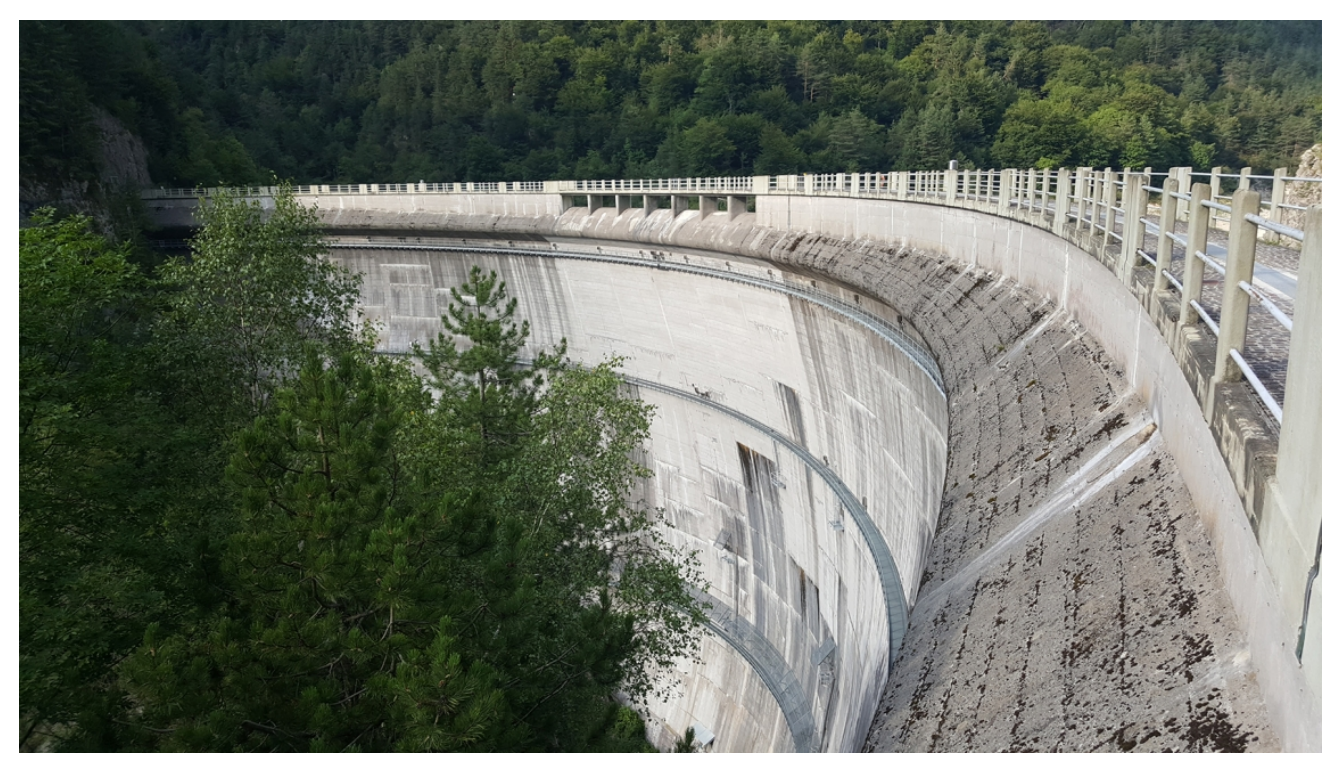

Figure 1. The spillway of Val Gallina Dam (photo taken by the authors on 11.08.2019). $150 \times 84 \mathrm{~mm}(300 \times 300 \mathrm{DPI})$ 


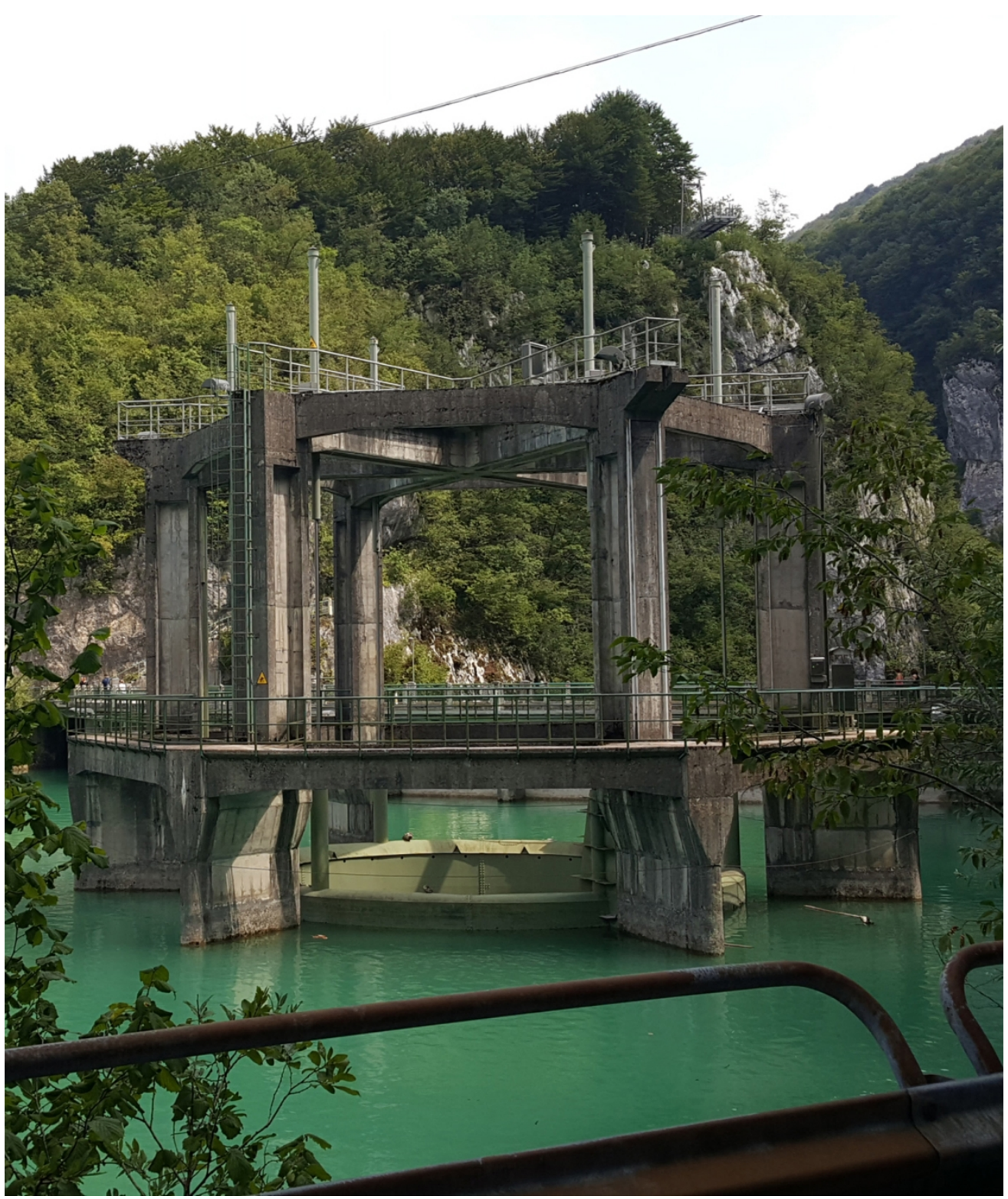

Figure 2. Intake structure of Barcis Dam (photo taken by the authors on 11.08.2019). $127 \times 150 \mathrm{~mm}(300 \times 300 \mathrm{DPI})$ 


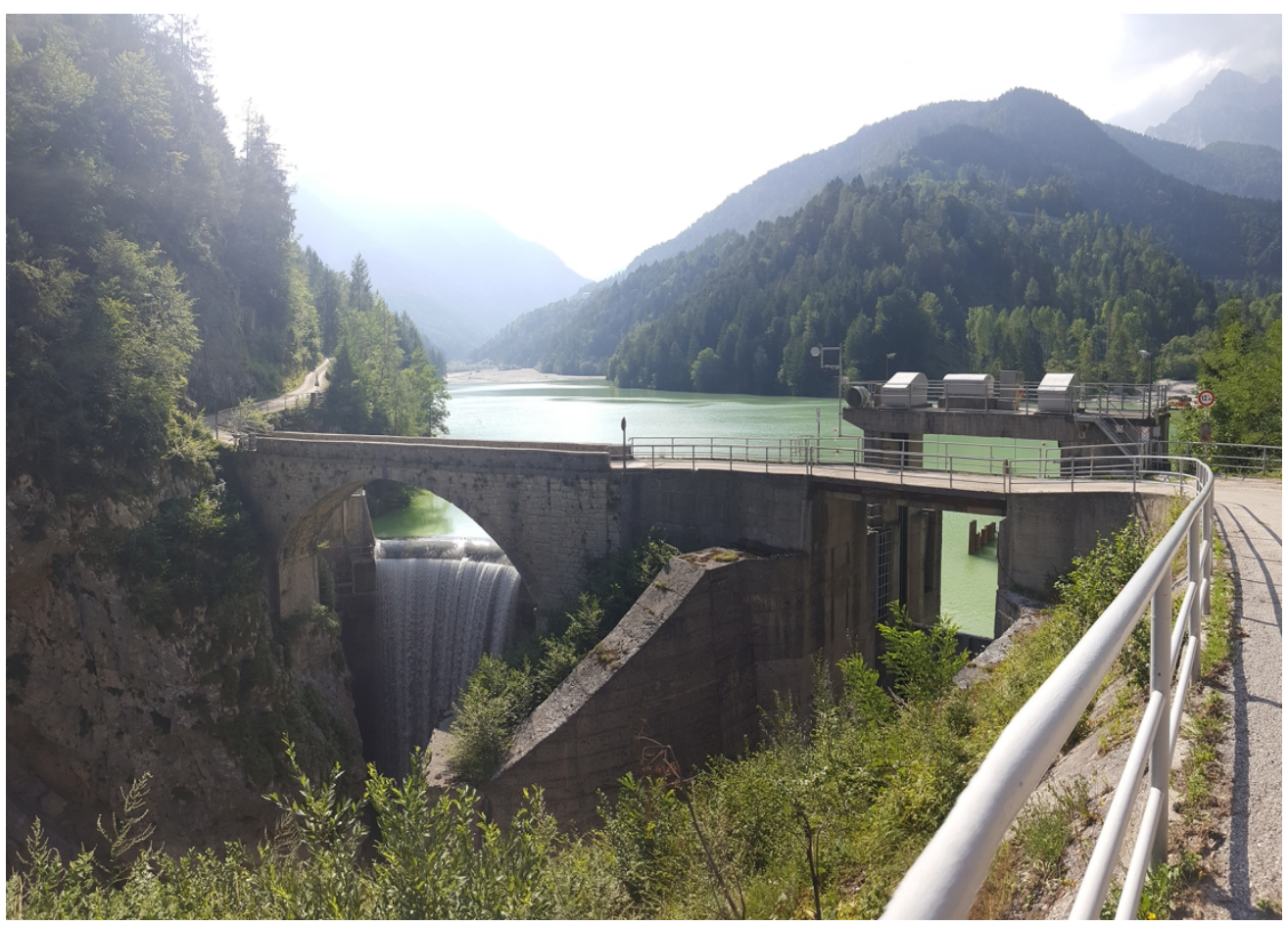

Figure 3. The dam and the intake structure of Valle di Cadore (photo taken by the authors on 11.08.2019). $150 \times 106 \mathrm{~mm}(300 \times 300$ DPI $)$ 


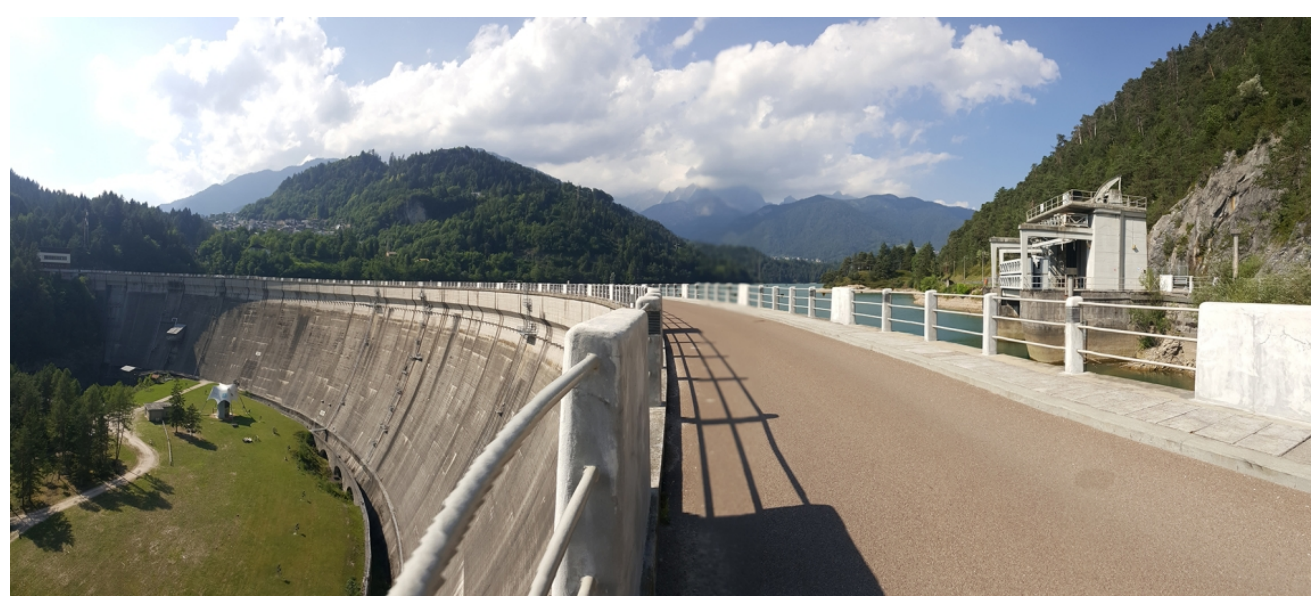

Figure 4. The dam and the intake structure of Pieve di Cadore (photo taken by the authors on 11.08.2019). $150 \times 66 \mathrm{~mm}(300 \times 300 \mathrm{DPI})$ 


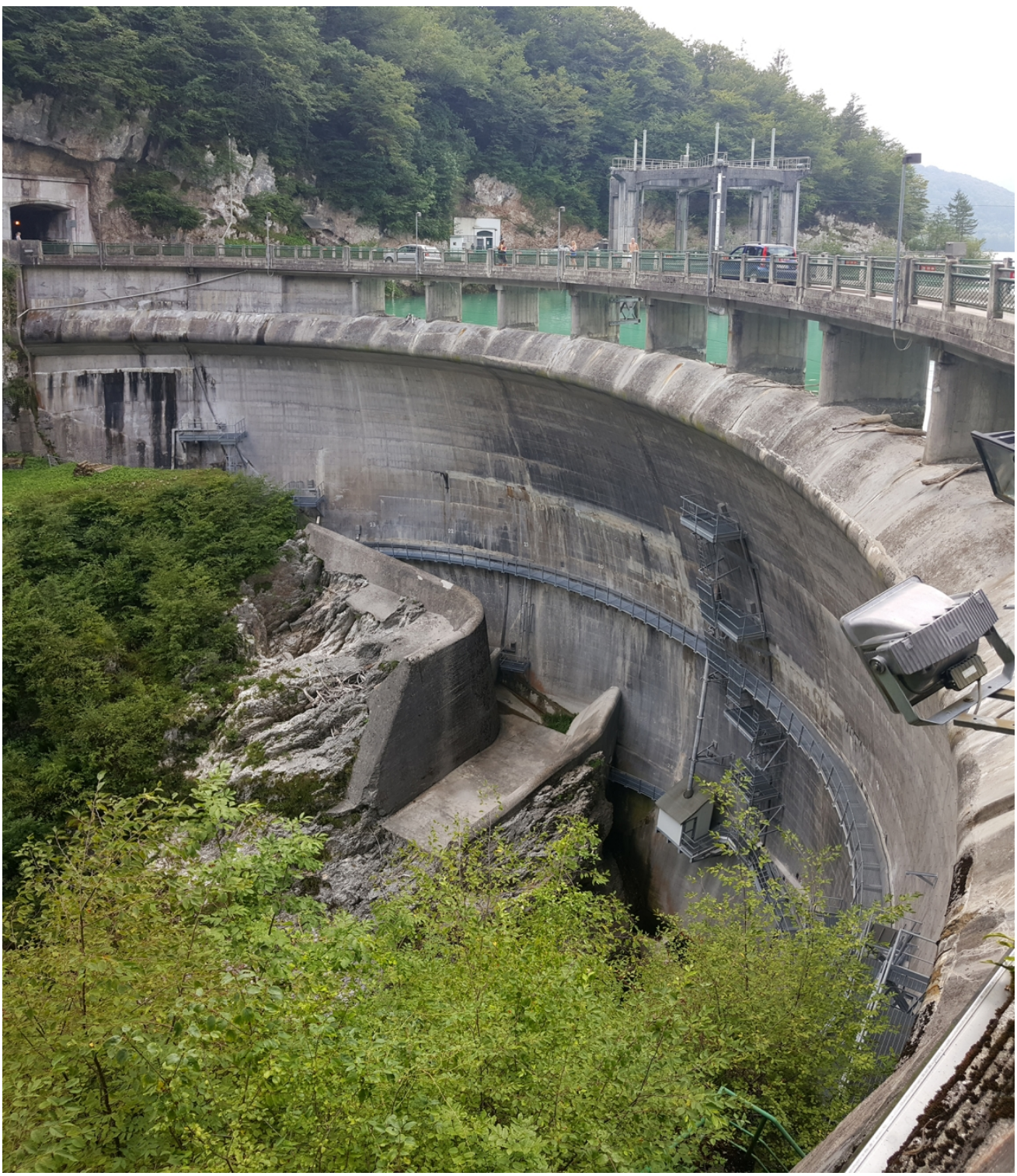

Figure 5. The double-curvature dam of Barcis (photo taken by the authors on 11.08.2019). $150 \times 172 \mathrm{~mm}(300 \times 300 \mathrm{DPI})$ 
Figure 6. Flowchart for the preservation/conservation and restoration of hydroelectric plants.

$182 \times 274 \mathrm{~mm}(300 \times 300 \mathrm{DPI})$

Continue using the plant for the original function of energy production.

Provide periodical and sustainable mainten
plant and the site.

"Provide and support the sustainability of communities related with
the plant (employers, workers, families) an inventory record the status of the plant periodically. Prepare "Develop and support public awareness regarding the cultural features of the plant as industrial heritage.
Does the presence of the facility endanger the neighboring natural or cultural assets? human settlements or other cultural properties<smiles></smiles>

CONSERVATION PRESERVATION RESTORATION

OF THE PLANT

* Compatibility

Minimum intervention

Durability
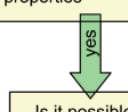

or minimize to reverse effects on the environment? to Further discussions and conservators.
Evaluate the selected new function.

*Is it reversible?

*Is it possible to implement with minimum mpact on:

-the authentict material, elements and the plant,

ant and the original culation and activity

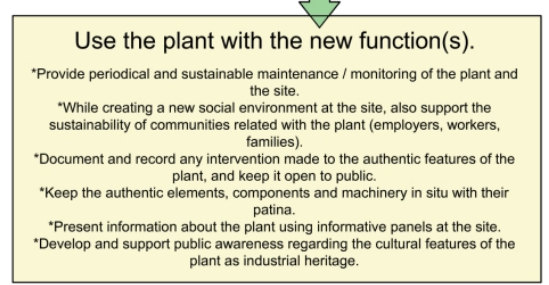




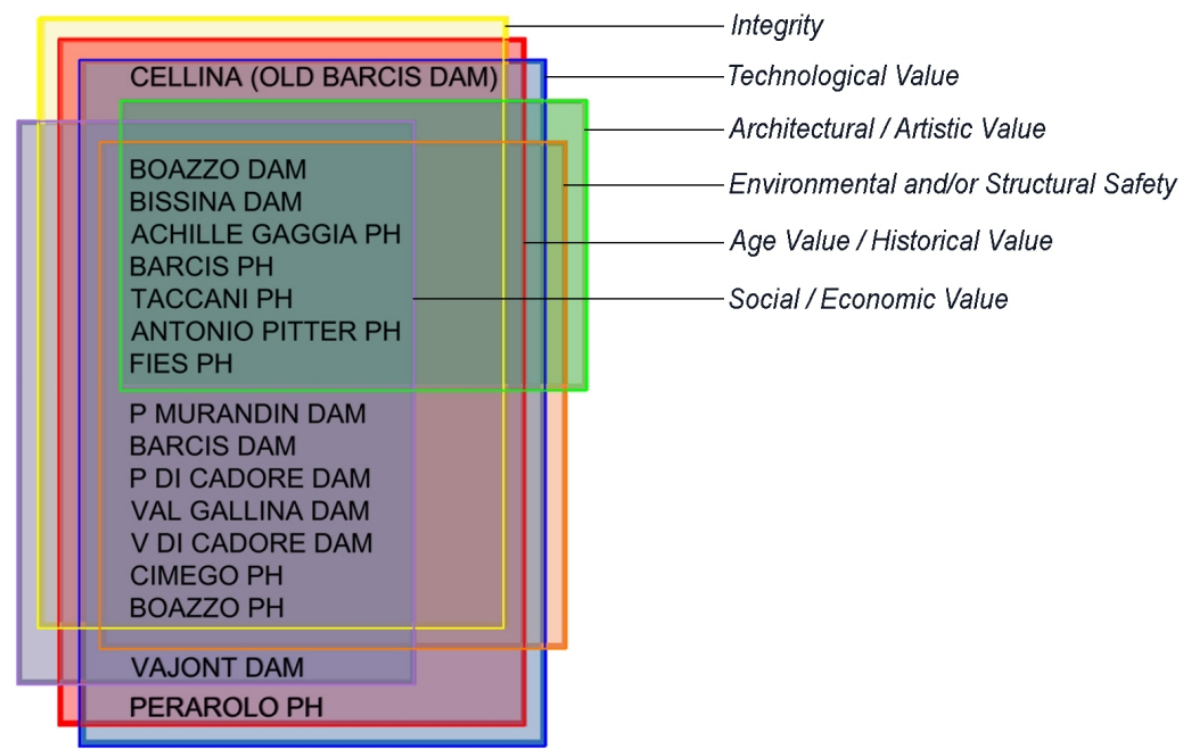

\begin{tabular}{|c|c|c|c|c|c|c|c|c|c|c|c|c|c|}
\hline CASE STUDY & 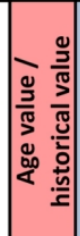 & 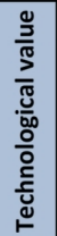 & 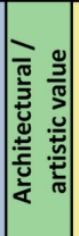 & 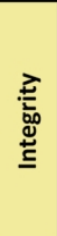 & 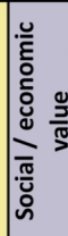 & 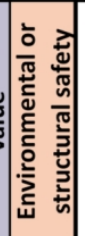 & CASE STUDY & 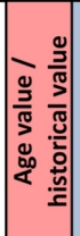 & 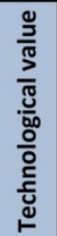 & 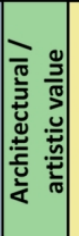 & 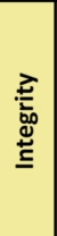 & 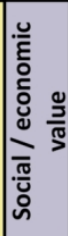 & 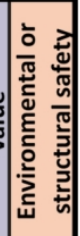 \\
\hline $\begin{array}{c}\text { PONTE MURANDIN } \\
\text { DAM } \\
\end{array}$ & $x$ & $\mathrm{x}$ & & $x$ & $x$ & $\mathrm{x}$ & $\begin{array}{c}\text { CIMEGO } \\
\text { POWERHOUSE } \\
\end{array}$ & $x$ & $x$ & & $\mathrm{x}$ & $x$ & $\mathrm{x}$ \\
\hline BOAZZO DAM & $x$ & $x$ & $\mathrm{x}$ & $x$ & $\mathrm{x}$ & $x$ & $\begin{array}{c}\text { BOAZZO } \\
\text { POWERHOUSE }\end{array}$ & $x$ & $\mathrm{x}$ & & $\mathrm{x}$ & $\mathrm{x}$ & $\mathrm{x}$ \\
\hline BISSINA DAM & & $\mathrm{x}$ & $\mathrm{x}$ & $x$ & $\mathrm{x}$ & $\mathrm{x}$ & $\begin{array}{l}\text { ACHILLE GAGGIA } \\
\text { POWERHOUSE }\end{array}$ & $x$ & $x$ & $x$ & $\mathrm{x}$ & $\mathrm{x}$ & $\mathrm{x}$ \\
\hline BARCIS DAM & $\mathrm{x}$ & $\mathrm{x}$ & & $x$ & $x$ & $\mathrm{x}$ & $\begin{array}{c}\text { BARCIS } \\
\text { POWERHOUSE }\end{array}$ & $x$ & $\mathrm{x}$ & $\mathrm{x}$ & $\mathrm{x}$ & $x$ & $\mathrm{x}$ \\
\hline $\begin{array}{l}\text { CELLINA DAM } \\
\text { (OLD BARCIS) }\end{array}$ & $\mathrm{x}$ & $\mathrm{x}$ & & $x$ & & & $\begin{array}{l}\text { PERAROLO } \\
\text { POWERHOUSE }\end{array}$ & $x$ & $\mathrm{x}$ & & & & \\
\hline PIEVE DI CADORE DAM & $\mathrm{x}$ & $\mathrm{x}$ & & $\mathrm{x}$ & $x$ & $x$ & $\begin{array}{c}\text { TACCANI } \\
\text { POWERHOUSE }\end{array}$ & $\mathrm{x}$ & $x$ & $x$ & $\mathrm{x}$ & $x$ & $x$ \\
\hline VAL GALLINA DAM & $\mathrm{x}$ & $x$ & & $\mathrm{x}$ & $x$ & $x$ & $\begin{array}{l}\text { ANTONIO PITTER } \\
\text { POWERHOUSE }\end{array}$ & $\mathrm{x}$ & $\mathrm{x}$ & $x$ & $\mathrm{x}$ & $\mathrm{x}$ & $\mathrm{x}$ \\
\hline VALLE DI CADORE DAM & $\mathrm{x}$ & $\mathrm{x}$ & & $x$ & $\mathrm{x}$ & $\mathrm{x}$ & FIES POWERHOUSE & $\mathrm{x}$ & $x$ & $\mathrm{x}$ & $\mathrm{x}$ & $\mathrm{x}$ & $x$ \\
\hline VAJONT DAM & $x$ & $\mathrm{x}$ & & & $x$ & & & & & & & & \\
\hline
\end{tabular}

Figure 7. Heritage assessment of the case studies.

$142 \times 172 \mathrm{~mm}(300 \times 300 \mathrm{DPI})$ 


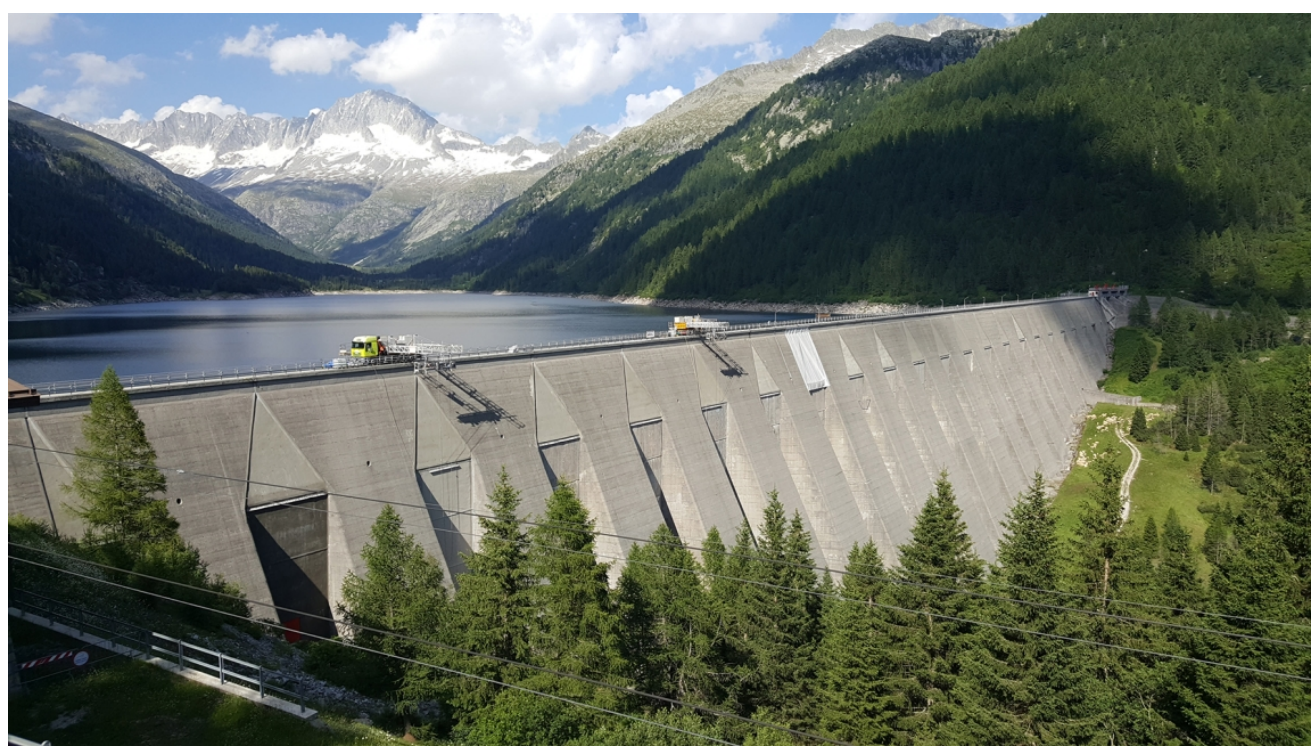

Figure 8. Cellular gravity dam (Marcello type) of Malga Bissina (photo taken by the authors on 05.07.2019). $150 \times 84 \mathrm{~mm}(300 \times 300 \mathrm{DPI})$ 

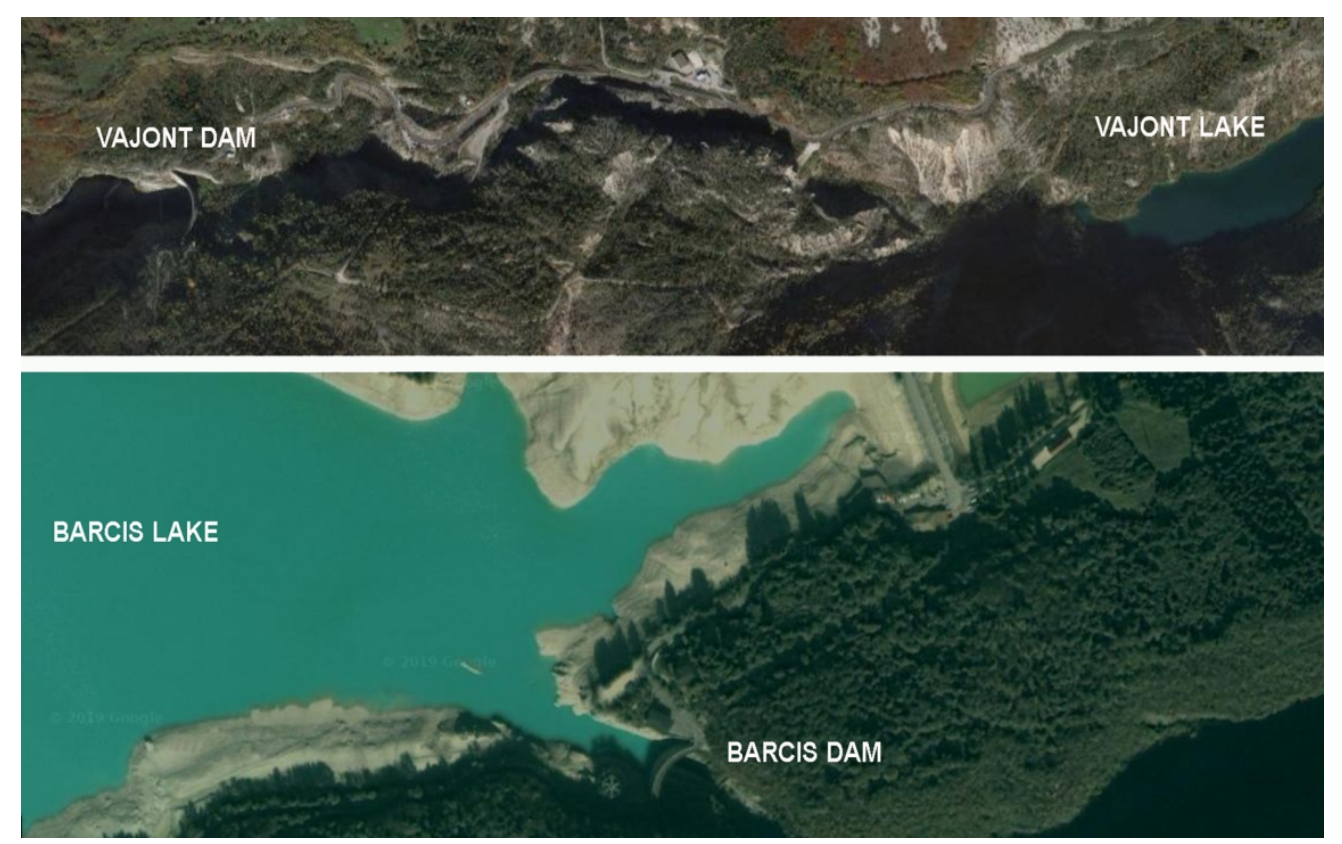

Figure 9. Aerial views of Vajont Dam and Barcis Dam (Google Earth).

$$
150 \times 94 \mathrm{~mm}(300 \times 300 \mathrm{DPI})
$$


Figure 10. Application of the flowchart for each case study.

$183 \times 275 \mathrm{~mm}(300 \times 300 \mathrm{DPI})$ 


\begin{tabular}{|c|c|c|c|c|c|c|c|}
\hline DAMS & $\begin{array}{l}\text { Photos at construction } \\
\text { (ANIDEL 1961, ENEL 1974) }\end{array}$ & \begin{tabular}{|c|}
$\begin{array}{c}\text { River and } \\
\text { Hydroelectric } \\
\text { System }\end{array}$ \\
\end{tabular} & $\begin{array}{c}\text { Construction } \\
\text { Period }\end{array}$ & Type & $\begin{array}{l}\text { Geometrical \& Geographical } \\
\text { Features }\end{array}$ & $\begin{array}{l}\text { Current } \\
\text { Status } \\
\text { (2019) }\end{array}$ & Current Photo (by the authors) 2019 \\
\hline $\begin{array}{c}\text { PONTE } \\
\text { MURANDIN }\end{array}$ & & $\begin{array}{l}\text { Chiese River } \\
\text { Hydroelectric } \\
\text { Development } \\
\text { of the Upper } \\
\text { Chiese River }\end{array}$ & 1954-1956 & $\begin{array}{c}\text { concrete } \\
\text { solid gravity } \\
\text { arched in plan }\end{array}$ & $\begin{array}{l}\text { Height of the crest: } 31.5 \mathrm{~m} \\
\text { Length of the crest: } 87 \mathrm{~m} \\
\text { Thickness of the crest: } 3.5 \mathrm{~m} \\
\text { Volume of the dam: } 8740 \mathrm{~m} 3 \\
\text { Normal water level: } 717 \text { m.a.s.l. } \\
\text { Storage capacity: } 0.33 \text { million m3 } \\
\text { Catchment area: } 57.81 \mathrm{~km} 2\end{array}$ & Active & \\
\hline BOAZZO & & $\begin{array}{l}\text { Chiese River } \\
\text { Hydroelectric } \\
\text { Development } \\
\text { of the Upper } \\
\text { Chiese River }\end{array}$ & 1954-1956 & $\begin{array}{c}\text { concrete / } \\
\text { a combination of } \\
\text { sections: } \\
\text {-in cellular gravity } \\
\text { (with hollow } \\
\text { elements) and } \\
\text {-in solid gravity }\end{array}$ & $\begin{array}{c}\text { Height of the crest: } 57.10 \mathrm{~m} \\
\text { Length of the crest: } 439.91 \mathrm{~m} \\
\text { Volume of the dam: } 78539 \mathrm{m3} \\
\text { N. water level: } 1224.50 \mathrm{~m} \text {.a.s.l. } \\
\text { Storage capacity: } 12.26 \text { million m3 } \\
\text { Catchment area: } 152.50 \mathrm{~km} 2\end{array}$ & Active & \\
\hline BISSINA & & $\begin{array}{l}\text { Chiese River } \\
\text { Hydroelectric } \\
\text { Development } \\
\text { of the Upper } \\
\text { Chiese River }\end{array}$ & 1955-1957 & \begin{tabular}{|c|} 
concrete \\
cellular gravity with \\
hollow elements \\
(Marcello type) \\
with solid gravity \\
buttresses
\end{tabular} & $\begin{array}{l}\text { Height of the crest: } 84 \mathrm{~m} \\
\text { Length of crest: } 563.40 \mathrm{~m} \\
\text { Volume of the dam: } 440000 \mathrm{~m} 3 \\
\text { Normal water level: } 1788 \text { ma.s.l. } \\
\text { Storage capacity: } 60.70 \text { million m3 } \\
\text { Catchment area: } 75.50 \mathrm{~km} 2\end{array}$ & $\begin{array}{l}\text { Active } \\
\text { Additional } \\
\text { sportive } \\
\text { activity } \\
\text { (Speed } \\
\text { rock- } \\
\text { climbing) }\end{array}$ & \\
\hline BARCIS & & $\begin{array}{c}\text { Cellina River } \\
\text { Hydroelectric } \\
\text { Development } \\
\text { of the Middle } \\
\text { and Lower } \\
\text { Cellina }\end{array}$ & 1952-1954 & $\begin{array}{c}\text { concrete } \\
\text { double-curvature } \\
\text { arched in plan }\end{array}$ & $\begin{array}{c}\text { Height of the crest: } 50.00 \mathrm{~m} \\
\text { Length of crest: } 71.38 \mathrm{~m} \\
\text { Volume of the dam: } 8094 \mathrm{~m} 3 \\
\text { Normal water level: } 402 \mathrm{~m} . \text {.a.s.l. } \\
\text { Storage capacity: } 21.98 \text { million m3 } \\
\text { Catchment area: } 392 \mathrm{~km} 2\end{array}$ & Active & \\
\hline $\begin{array}{l}\text { CELLINA } \\
\text { (OLD BARCIS) }\end{array}$ & & $\begin{array}{c}\text { Cellina River } \\
\text { Hydroelectric } \\
\text { Development } \\
\text { of the Middle } \\
\text { Cellina }\end{array}$ & 1900-1905 & $\begin{array}{c}\text { stone masonry with } \\
\text { cement mortar } \\
\text { solid gravity } \\
\text { straight in plan }\end{array}$ & $\begin{array}{c}\text { Height of the crest: } 33.60 \mathrm{~m} \\
\text { Length of crest: } 41.40 \mathrm{~m} \\
\text { Volume of the dam: } 10700 \mathrm{~m} 3 \\
\text { Normal water level: } 342.60 \mathrm{~m} \text {.a.s.l. } \\
\text { Storage capacity: } 0.15 \text { million m3 } \\
\text { Catchment area: } 424 \mathrm{~km} 2\end{array}$ & Inactive & \\
\hline PIEVE DI CADORE & & $\begin{array}{c}\text { Piave River } \\
\text { Hydroelectric } \\
\text { Development } \\
\text { of Piave-Boite } \\
\text { Vajont }\end{array}$ & 1946-1949 & $\begin{array}{l}\text { concrete } \\
\text { solid gravity } \\
\text { arched in plan }\end{array}$ & $\begin{array}{l}\text { Height of the crest: } 112 \mathrm{~m} \\
\text { Length of crest: } 410 \mathrm{~m} \\
\text { Volume of the dam: } 377000 \mathrm{~m} 3 \\
\text { Normal water level: } 683.5 \mathrm{~m} \text {.a.s.l. } \\
\text { Storage capacity: } 68.5 \text { million m3 } \\
\text { Catchment area: } 818.5 \mathrm{~km} 2\end{array}$ & $\begin{array}{l}\text { Active } \\
\text { Additional } \\
\text { sportive } \\
\text { activity } \\
\text { (climbing) }\end{array}$ & \\
\hline VAL GALLINA & & \begin{tabular}{|c|} 
River: Rio di \\
Val Gallina \\
Hydroelectric \\
Development \\
of Piave-Boite- \\
Vajont
\end{tabular} & 1949-1951 & $\begin{array}{c}\text { concrete } \\
\text { double-curvature } \\
\text { arched in plan }\end{array}$ & $\begin{array}{l}\text { Height of the crest: } 92.37 \mathrm{~m} \\
\text { Length of crest: } 228 \mathrm{~m} \\
\text { Volume of the dam: } 99100 \mathrm{~m} 3 \\
\text { Normal water level: } 677 \text { m.a.s.l. } \\
\text { Storage capacity: } 6.40 \text { million m3 } \\
\text { Catchment area: } 14.40 \mathrm{~km} 2\end{array}$ & Active & \\
\hline $\begin{array}{l}\text { VALLE DI } \\
\text { CADORE }\end{array}$ & & $\begin{array}{c}\text { River: Boite } \\
\text { Hydroelectric } \\
\text { Development } \\
\text { of Piave-Boite } \\
\text { Vajont }\end{array}$ & 1949-1950 & $\begin{array}{c}\text { concrete } \\
\text { double-curvature } \\
\text { arched in plan }\end{array}$ & $\begin{array}{l}\text { Height of the crest: } 61.25 \mathrm{~m} \\
\text { Length of crest: } 37.5 \mathrm{~m} \\
\text { Volume of the dam: } 4607 \mathrm{~m} 3 \\
\text { Normal water level: } 706.5 \mathrm{~m} \text {.a.s.l. } \\
\text { Storage capacity: } 4.90 \text { million m3 } \\
\text { Catchment area: } 380.20 \mathrm{~km} 2\end{array}$ & Active & \\
\hline VANONT & & \begin{tabular}{|c|} 
River: Piave \\
Hydroelectric \\
Development \\
of Piave-Boite \\
Vajont
\end{tabular} & 1956-1961 & $\begin{array}{c}\text { concrete } \\
\text { double-curvature } \\
\text { arched in plan }\end{array}$ & $\begin{array}{c}\text { Height of the crest: } 261.60 \mathrm{~m} \\
\text { Length of crest: } 190.15 \mathrm{~m} \\
\text { Volume of the dam: } 360000 \mathrm{~m} 3 \\
\text { Normal water level: } 579.36 \mathrm{~m} \text {.a.s.l. } \\
\text { Storage capacity: } 168.75 \text { million m3 }\end{array}$ & \begin{tabular}{|l} 
Failed dam \\
/ out of \\
active use
\end{tabular} & \\
\hline
\end{tabular}

Table 1. Technical features of the case studies - DAMS.

$172 \times 194 \mathrm{~mm}(300 \times 300$ DPI $)$ 


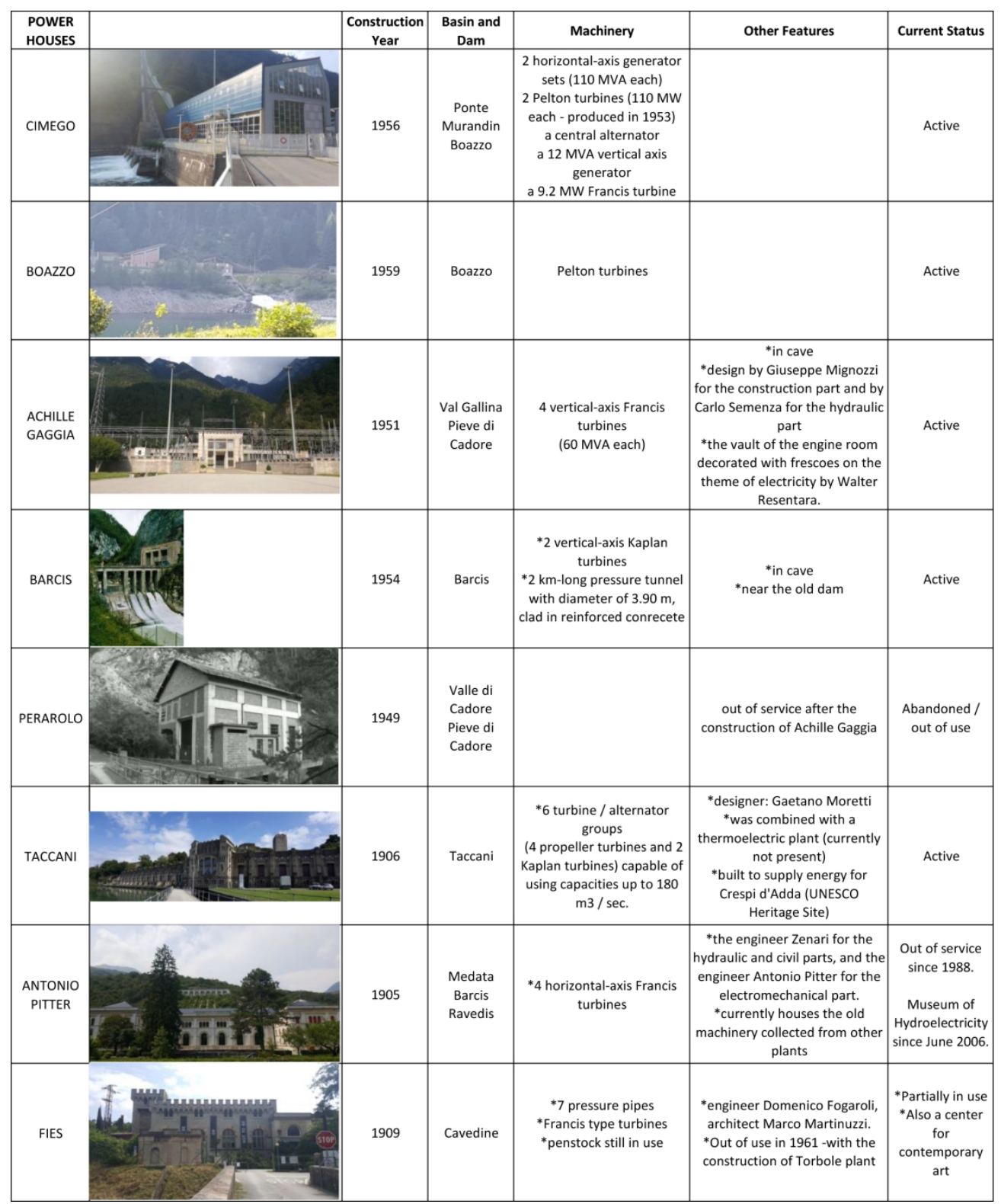

Table 2. Technical features of the case studies - POWER HOUSES.

$172 \times 208 \mathrm{~mm}(300 \times 300$ DPI $)$ 